\title{
Effect of ultrasound power on physicochemical and rheological properties of yoghurt drink produced with thermosonicated milk
}

\author{
Oguz Gursoy ${ }^{1 *}$, Yusuf Yilmaz', Ozge Gokce², Kubra Ertan' ${ }^{1}$ \\ ${ }^{1}$ Department of Food Engineering, Faculty of Engineering and Architecture, Mehmet Akif Ersoy University, Burdur, Turkey, ${ }^{2}$ Scientific and \\ Technological Application and Research Centre, Mehmet Akif Ersoy University, Burdur, Turkey
}

\section{A B S T R A C T}

\begin{abstract}
The aim of the study was to determine the effect of ultrasound power on some selected quality parameters of yogurt drink produced with thermosonicated milk. Ultrasonication treatments for raw milk samples preheated to $70^{\circ} \mathrm{C}$ were carried out at different ultrasound powers $(100,125$ and $150 \mathrm{~W})$. Yogurt drinks were produced with milk samples processed with thermosonication or conventional heating $\left(10 \mathrm{~min}\right.$ at $\left.90^{\circ} \mathrm{C}\right)$. Thermosonication treatment did not influence proximate composition and color properties of samples; however, it decreased serum separation values significantly while increasing apparent viscosity values at higher ultrasound power. Rheological measurements indicated that all yogurt drink samples exhibited a non-Newtonian behavior. In conclusion, thermosonication treatment could be successfully used in the production of yoghurt drink and improve its major quality parameters such as delayed serum separation and increased apparent viscosity.
\end{abstract}

Keywords: Serum separation; Thermosonication; Ultrasound; Viscosity; Yoghurt drink

\section{INTRODUCTION}

Efforts in the development of novel technologies have recently increased in order to meet consumer expectations for high quality food products. Ultrasound treatment is one of these technologies with a potential in food industry. Ultrasound or sonication refers to an oscillating sound pressure wave with a frequency greater than the upper limit of the human hearing range, i.e. above $16 \mathrm{kHz}$ (Dolatowski et al., 2007; Soria and Villamiel, 2010). During sonication, longitudinal waves are formed in a liquid medium, which creates alternating compression and expansion regions. Pressure change in liquid forms small gas bubbles. These bubbles continue to expand, and a volume is reached where they cannot absorb more energy. At this point, a rapid condensation is obtained. This phenomenon is called cavitation (Jambrak, 2011) or acoustic cavitation (Chandrapal et al., 2012). Cavitation may result in pressure over $101 \mathrm{MPa}$, and large amounts of energy are released. This energy heats up regions around the bubbles and cause chemical reactions. Cavitation may occur in the applications of low frequency $(20-100 \mathrm{kHz})$ and high power ultrasound used in food processing. Extremely high temperature (up to $5000 \mathrm{~K}$ ) and pressure (up to $50 \mathrm{MPa}$ ) build up in cavitation bubbles (Jambrak, 2011). Reactive radicals can be formed in these bubbles. Besides chemical reactions, severe physical forces such as microjets, shear forces, shock waves and turbulence can occur by the acoustic cavitation. For example, stability of capsules containing pharmaceutical and food ingredients formed by ultrasonication can be substantially enhanced by the chemical crosslinking between protein molecules formed during sonication process (Chandrapal et al., 2012). According to the effects they form in a medium, ultrasonic frequencies can be classified as low frequencyhigh power $(20-100 \mathrm{kHz})$, medium frequency-medium power $(100 \mathrm{kHz}-1 \mathrm{MHz})$ and high frequency-low power (1-10 Mhz) (Bhaskarachary et al., 2009).

High intensity ultrasound treatment may be applied on its own, in combined with moderate heat (thermosonication, TS) or combined with heat and pressure (manothermosonication,

\footnotetext{
${ }^{*}$ Corresponding author:

Oguz Gursoy, Ph.D., Associate Professor, Mehmet Akif Ersoy University, Faculty of Engineering and Architecture, Department of Food
} Engineering, TR-15030 Burdur, Turkey. Tel.: +902482132723, Fax: +902482132704, E-mail: ogursoy@yahoo.com 
MTS). In the literature, there are a variety of research and review articles regarding the applications of ultrasound treatments in food industry (Mason et al., 1996; Knorr et al., 2004; Dolatows Suzuki et al., 2007; Riener et al., 2009; Carcelen et al., 2012; Jambrak et al., 2012; Pingret et al., 2013). Ultrasonication has been used in dairy industry in the field of research and development for various purposes such as food preservation, regulation of enzyme activity and improvement of microstructure by ingredient interaction. The physical effects enhanced by ultrasonication include the homogenization of fat globules, improvement of whey ultrafiltration, viscosity development, lactose crystallization, yoghurt production with improved rheological properties, reduction of total fermentation time of yoghurt and cutting of cheese blocks (Chandrapal et al., 2012).

Yoghurt and yoghurt-like fermented milk products have been widely consumed throughout the world. Differences in the production techniques of yoghurt drink is critical for the production of yoghurt drink with different flavor (Kocak and Avsar, 2010). Two major methods are used industrially to produce yoghurt drinks, dilution of yoghurt with water (Atamer, 1986) and the incorporation of starter cultures to standardized milk (Colakoglu and Gursoy, 2011, Akkaya et al., 2015). Plain yoghurt drinks are popular in Central Asia, Anatolia, Balkans and the Middle East while yoghurt drinks with fruits and sweeteners are mostly preferred in Europe and the US (Colakoglu and Gursoy, 2011).

Optimal structural characteristics such as viscosity, gel structure, water holding capacity, particle size, particle density and particle distribution are the most important factors determining consumer preferences for yoghurt drinks. Serum separation and optimum consistency have been industrially used as quality parameters for commercial production. The effect of ultrasonication on the serum separation and the physicochemical and structural properties of yoghurt drinks have been previously reported by Ertugay et al. (2012) and Erkaya et al. (2015); however, these studies are focused on the application of ultrasound and/or thermosonication process on final products rather than raw milk. In this present study, the effect of ultrasound power on the physicochemical and rheological properties of yoghurt drink produced with thermosonicated milk was determined.

\section{MATERIALS AND METHODS}

\section{Materials}

Raw cow milk samples were obtained from local farms in Burdur, Turkey. Analytical grade chemicals were used in chemical analyses.

\section{Thermosonication}

Thermosonication treatments were performed using an ultrasonic processor (Bandelin Sonopuls UW3200, Germany) working at a constant frequency of $24 \mathrm{kHz}$. An ultrasonic probe (TT13) with a diameter of $13 \mathrm{~mm}$ was attached to the processor. Standardized milk samples of $800 \mathrm{~mL}$ were transferred into beakers $(1 \mathrm{~L})$ in a circulating water bath and equilibrated for $5 \mathrm{~min}$ at $70^{\circ} \mathrm{C}$. The ultrasonic probe was immersed in the geometrical center of a beaker. Ultrasonic processor was turned on for $15 \mathrm{~min}$ with a power output of 100,125 or $150 \mathrm{~W}$.

\section{Yoghurt drink production}

Yoghurt drinks were manufactured in the laboratory. The approximate chemical composition of raw cow milk included $11.56 \%$ total solids, $3.02 \%$ fat, $3.01 \%$ protein, $4.74 \%$ lactose, $0.15 \%$ acidity (as $\%$ lactic acid) and $\mathrm{pH}$ was 6.47. Raw milk sample was standardized to a 7\% total solid content with distilled water. Conventionally heat treated samples at $90^{\circ} \mathrm{C}$ for $10 \mathrm{~min}$ were used as control, and both heat treated and thermosonicated milk samples were cooled to $45 \pm 1{ }^{\circ} \mathrm{C}$ and inoculated with $2.5 \%$ of commercial starter cultures including Streptococcus thermophilus and Lactobacillus delbrueckii subsp. bulgaricus (YO-MIX ${ }^{\mathrm{TM}}$ 496, Danisco, France). Inoculated samples were incubated at $43.5^{\circ} \mathrm{C}$ until the $\mathrm{pH}$ of $4.5 \pm 0.1$. After incubation, fermented milk samples were rapidly cooled to $20 \pm 1^{\circ} \mathrm{C}$ in a cold water bath by mixing thoroughly with a mechanical overhead stirrer (Mtops MS3040, Misung Scietific Co. Ltd., Korea) at $200 \mathrm{rpm}$ for $2 \mathrm{~min}$. All samples were stored at $4 \pm 1^{\circ} \mathrm{C}$ up to 10 days. Samples were analyzed at the $1^{\text {st }}, 5^{\text {th }}$ and $10^{\text {th }}$ days of storage. Yoghurt drink samples were produced in triplicates.

\section{Chemical and physicochemical analyses}

Total solids, fat, lactose and protein contents of raw milk samples were analysed by an infrared milk analyser (Bentley B150, Bentley Instruments Inc., USA). The $\mathrm{pH}$ values of milk and yoghurt drink samples were determined by a $\mathrm{pH}$ meter (Jenco 6173, Jenco, San Diego, CA, USA). Titratable acidity values of milk and yoghurt drink samples were determined according to TS 1018 (Anonymous, 1981) and Oysun (2001), respectively. Yoghurt drink samples were analyzed for total solid contents (ISO/IDF, 2010), fat (Gerber method) (Oysun, 2001) and total nitrogen [Dumas method by the Dumatherm analyzer (Gerhardt GmbH \& Co. KG, Königswinter, Germany)]. Protein content was calculated by using the factor 6.38 .

\section{Serum separation}

Yoghurt drink samples were transferred into $100 \mathrm{~mL}$ volumetric cylinders and stored at $4^{\circ} \mathrm{C}$ for 10 days. Serum separation was determined as the volume of separated 
serum at the top on days 1, 5 and 10 (Koksoy and Kilic, 2003).

\section{Rheological analyses}

Rheological measurements were carried out using a Brookfield viscometer (Model DV-II Pro, Brookfield Engineering Laboratories, USA) with a spindle of RV2. Yoghurt drink samples $(0.8 \mathrm{~L})$ in $1 \mathrm{~L}$ beakers was used for measurements at a constant temperature of $5 \pm 1^{\circ} \mathrm{C}$. Analyses were performed at 10 s intervals and repeated 3 times. Measurements were taken at shear rates between 30 and $120 \mathrm{rpm}$. Appearent viscosity and torque $(\%)$ values for each shear rate were recorded during rheological measurements. Flow behavior indices (n) and consistency coefficients $\left(\mathrm{K}, \mathrm{Pa} \cdot \mathrm{s}^{\mathrm{n}}\right)$ were calculated by using the power law model, $\delta=\mathrm{K}(\gamma)^{\mathrm{n}}$ where $\delta$ is shear stress $(\mathrm{Pa})$ and $\gamma$ shear rate $\left(\mathrm{s}^{-1}\right)$ (Steffe, 1996).

\section{Color measurement}

Color values of yoghurt drink samples were determined in CIE (Commission International de L'Eclairage) scale of $\mathrm{L}^{*}, \mathrm{a}^{*}$ and $\mathrm{b}^{*}$ by a tristimulus colorimeter (Model CR-400, Konica Minolta, Japan). Color measurements were taken by using reflectance specular included with D65 illuminant, $10^{\circ}$ observer angle and 8 -mm aperture. Each yoghurt drink sample $(20 \mathrm{~mL})$ was placed in an optical glass cell provided by the manufacturer of the colorimeter (diameter of the cell $34 \mathrm{~mm}$ ) and four measurements were taken at 3 -second intervals at approximately $5^{\circ} \mathrm{C}$. Measurements were averaged for each sample. For lightness $\left(\mathrm{L}^{*}\right), 0$ indicates black and 100 indicates white. Positive values of $\mathrm{a}^{*}$ and $\mathrm{b}^{*}$ indicate red and yellow, respectively while negative values of $\mathrm{a}^{*}$ and $\mathrm{b}^{*}$ indicate green and blue, respectively.

\section{Statistical analyses}

Analysis of variance (ANOVA) of the SAS software program (The SAS System for Windows 9.0, Chicago, USA) was used to determine statistically significant differences. Separation of means for significant differences was conducted using the Duncan's multiple-range test at $\alpha=0.05$ level. Data were presented as means of three replicates ( \pm standard deviation).

\section{RESULTS AND DISCUSSION}

\section{Proximate composition of yoghurt drinks}

Total solids, protein and fat contents of yoghurt drink samples are presented in Table 1. The composition of control and experimental yoghurt drinks was very similar. Thermosonication treatment, storage time and their interaction had an insignificant influence on the total solids, protein and fat content of yoghurt drinks ( $\mathrm{p}>0.05)$.

Acidity affects major storage stability parameters such as serum separation and rheological properties of yoghurt drinks (Ozdemir and Kilic, 2004). Titratable acidity values of yoghurt drink samples during storage are shown in Fig. 1. There were insignificant differences $(p>0.05)$ in titratable acidity values between control samples and yoghurt drinks produced with thermosonicated milk. Similar results were reported in yoghurt drinks by Uzunoglu (2012) and Erkaya et al. (2015). Storage period influenced the acidity values significantly $(\mathrm{p}<0.05)$ while its interaction with thermosonication treatment was insignificant ( $p>0.05)$. In general, acidity values of all samples gradually increased after the first day of storage until the $10^{\text {th }}$ day. Accordingly, when all the titratable acidity values of yoghurt drink samples considered ( $\mathrm{n}=12$ per group), an average titratable acidity value of $0.43 \%$ at the beginning of storage increased to $0.48 \%$ and $0.52 \%$ after 5 and 10 days of storage, respectively. Similar results were noted by Tamucay-Ozunlu and Kocak (2010a) who reported that acidity values of yoghurt drinks increased from $0.46 \%$ to $0.52 \%$ during storage period.

Thermosonication treatment and its interaction with storage period had an insignificant influence on the $\mathrm{pH}$ values of yoghurt drink samples $(\mathrm{p}>0.05)$ (Table 2). The change pattern of $\mathrm{pH}$ values for yoghurt drinks in all samples was very similar during 10 days of storage. All $\mathrm{pH}$ values of yoghurt drink samples decreased during storage period $(\mathrm{p}<0.05) . \mathrm{pH}$ values of yoghurt drinks slightly decreased at the $5^{\text {th }}$ day of storage, then slightly increased at the $10^{\text {th }}$ day but this change was statistically insignificant $(p>0.05)$ except for the sample produced with

Table 1: Approximate composition and color values of yoghurt drink samples at the first day of storage $(n=3)$

\begin{tabular}{lcccc}
\hline Parameters & \multicolumn{4}{c}{ Sample/ultrasound power } \\
\cline { 2 - 5 } & Control & $\mathbf{1 0 0} \mathbf{W}$ & $\mathbf{1 2 5} \mathbf{W}$ & $\mathbf{1 5 0} \mathbf{~ W}$ \\
\hline Total solids (\%) & $7.04 \pm 0.01$ & $7.02 \pm 0.13$ & $6.96 \pm 0.08$ & $7.06 \pm 0.04$ \\
Protein (\%) & $1.14 \pm 0.34$ & $1.05 \pm 0.09$ & $0.95 \pm 0.08$ & $1.20 \pm 0.10$ \\
Fat (\%) & $1.88 \pm 0.10$ & $1.85 \pm 0.06$ & $1.88 \pm 0.10$ & $1.85 \pm 0.06$ \\
Color value L* $^{*}$ & $87.83 \pm 4.28$ & $89.19 \pm 2.21$ & $89.71 \pm 2.41$ & $90.26 \pm 1.33$ \\
Color value a* $^{*}-3.03 \pm 0.86$ & $-2.61 \pm 0.42$ & $-2.81 \pm 0.49$ & $-2.81 \pm 0.07$ \\
Color value b* & $8.56 \pm 1.68$ & $7.84 \pm 0.98$ & $8.05 \pm 1.16$ & $7.93 \pm 0.09$ \\
\hline
\end{tabular}

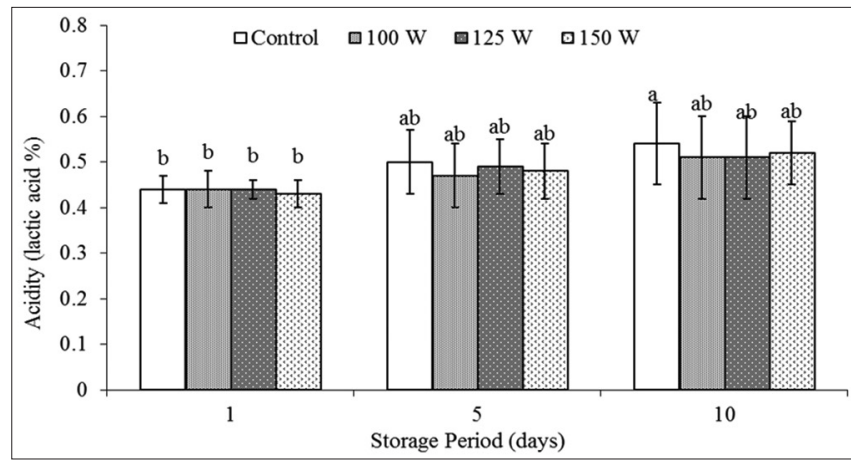

Fig 1. Acidity values of control and yoghurt drinks produced with milk thermosonicated at different ultrasound powers $(n=3)$. Different letters in the figure indicate statistically significant differences $(p<0.05)$ 
milk thermosonicated at $100 \mathrm{~W}(\mathrm{p}<0.01)$. Tamucay-Ozunlu and Kocak (2010b) reported that $\mathrm{pH}$ values of yoghurt drinks were 4.52 to 4.45 at the beginning and end of storage period, respectively. In another study, $\mathrm{pH}$ values of yoghurt drinks increased from 4.30 to 4.10 during 10 days of storage (Tonguc, 2006). Our results were in good agreement with these studies.

\section{Serum separation}

Serum separation in acidic fermented dairy products is the formation of serum phase at the top, which is due to the loss of water from a continuous protein matrix. Serum separation is one of the main quality parameters in yoghurt and yoghurt drink. The results of this research indicated that thermosonication process significantly decreased the serum separation of yoghurt drink during storage (Table 3). Individual effects of thermosonication process and storage and their interaction on serum separation were found statistically significant $(p<0.01)$ (Table 3). Increasing ultrasound power reduced serum separation while serum separation increased with the storage period. Initially serum separation values of yoghurt drink samples were found statistically similar. Throughout the storage, serum separation was not observed in yoghurt drinks produced with milk treated at $150 \mathrm{~W}$ ultrasound power for $15 \mathrm{~min}$. Riener et al. (2009) reported increased water holding capacity in yoghurts made with thermosonicated milk. In another study, increasing ultrasound power applied directly to yoghurt drink samples reduced serum separation (Ertugay et al., 2012). The authors reported that serum separation value was about $34 \%$ in control samples while it reduced to about $10 \%$ in samples treated with $44.54 \mathrm{~W}$ ultrasound

\begin{tabular}{|c|c|c|c|}
\hline \multirow{2}{*}{$\begin{array}{l}\text { Sample/ultrasound } \\
\text { power }\end{array}$} & \multicolumn{3}{|c|}{ Storage time (day) } \\
\hline & 1 & 5 & 10 \\
\hline Control & $4.48 \pm 0.02^{\mathrm{ab}}$ & $4.10 \pm 0.10^{e}$ & $4.24 \pm 0.11^{\text {cde }}$ \\
\hline $100 \mathrm{~W}$ & $4.49 \pm 0.07^{a b}$ & $4.18 \pm 0.09^{\mathrm{de}}$ & $4.37 \pm 0.26^{a b c}$ \\
\hline $125 \mathrm{~W}$ & $4.51 \pm 0.01^{\mathrm{ab}}$ & $4.18 \pm 0.09^{d e}$ & $4.34 \pm 0.21^{\mathrm{bcd}}$ \\
\hline $150 \mathrm{~W}$ & $4.53 \pm 0.02^{\mathrm{a}}$ & $4.17 \pm 0.09^{\mathrm{de}}$ & $4.25 \pm 0.13^{\text {cde }}$ \\
\hline
\end{tabular}

a-e Different letters indicate statistically significant differences across the table $(\mathrm{p}<0.05)$

Table 3: Serum separation values of yoghurt drink samples $(\%)$ during storage $(n=3)$

\begin{tabular}{|c|c|c|c|}
\hline \multirow{2}{*}{$\begin{array}{l}\text { Sample/ultrasound } \\
\text { power }\end{array}$} & \multicolumn{3}{|c|}{ Storage (day) } \\
\hline & 1 & 5 & 10 \\
\hline Control & $2.75 \pm 0.50^{\text {ef }}$ & $13.00 \pm 1.15^{b}$ & $21.50 \pm 2.38^{\mathrm{a}}$ \\
\hline $100 \mathrm{~W}$ & $1.25 \pm 1.50^{\dagger}$ & $6.75 \pm 5.50^{\text {cde }}$ & $11.25 \pm 6.65^{\mathrm{bc}}$ \\
\hline $125 \mathrm{~W}$ & $1.00 \pm 1.54^{f}$ & $4.50 \pm 4.04^{\text {def }}$ & $7.75 \pm 6.07^{\mathrm{cd}}$ \\
\hline $150 \mathrm{~W}$ & $0.00 \pm 0.00^{\dagger}$ & $0.00 \pm 0.00^{f}$ & $0.00 \pm 0.00^{f}$ \\
\hline
\end{tabular}

a-f Different letters indicate statistically significant differences across the table $(\mathrm{p}<0.05)$ power for 4 minutes. Our results were in accordance with these studies.

Ultrasonication itself generates considerable amount of heat in a liquid matrix (Demirdoven \& Baysal, 2009; Riener et al., 2009), and the control of this heat is significant in determining the individual effect of ultrasonication on the physical and functional properties of liquid foods like milk. In a study by Nguyen and Anema (2010), the effect of ultrasound on the properties of skim milk used in the formation of acid gels was distinguished from the heat-related effects of ultrasonication. The authors sonicated skim milk at $50 \mathrm{~W}$ for up to $30 \mathrm{~min}$ at different temperatures $\left(20,40,60\right.$ and $\left.70^{\circ} \mathrm{C}\right)$ to produce acid gels, and the maximum firmness (final $G^{\prime}$ ) values were obtained for the skim milk ultrasonicated at 60 or $70^{\circ} \mathrm{C}$ in $15 \mathrm{~min}$, which were very similar to that for the traditionally heated milk. In this study, ultrasound effect was found less influential on the modification of skim milk properties than the heat generated effect during ultrasonication. The authors also reported that ultrasonication slightly reduced the particle size of the casein micelles and produced acid gels with slightly increased final $G$ ' values, and these effects were additive to those of heating. Heat generated effects were reported to include the denaturation of the whey proteins, the modification of the particle size of the casein micelles and influences on the interaction of the denatured whey proteins with the casein micelles. This present study was mainly focused on the thermosonication effect on yoghurt drink properties, and increases in viscosity and decreases in serum separation values of yoghurt drinks in comparison to conventional heat treatment were mostly from the combined effect of ultrasound power (100, 125 and $150 \mathrm{~W}$ for $15 \mathrm{~min})$ and heat treatment $\left(70^{\circ} \mathrm{C}\right.$ for 15 min) applied.

\section{Viscosity}

Rheological properties of yoghurt drink produced by the traditional method and thermosonicated raw milk at different ultrasound power are presented in Table 4. High $\mathrm{R}^{2}$ values (ranging from 0.974 to 0.996 ) indicated that the power law model was appropriate for determining the rheological properties of yoghurt drink samples. Depending on the ultrasound power used, ultrasonication process of raw milk at $70^{\circ} \mathrm{C}$ increased the apparent viscosities of yoghurt drink samples. Apparent viscosity values increased with an increase in the ultrasound power. The viscosity of yoghurt and yoghurt-like fermented dairy products is one of the most important quality parameters and physical structure is directly related to the viscosity of the products. The physical structure of these products is associated with the physical interactions of proteins with each other and entrapping serum and fat globules in protein network (Lucey, 2004; Riener et al., 2009). In yoghurt and yoghurt 
Table 4: Rheological properties of yoghurt drinks produced with milk thermosonicated at different ultrasound powers ( $\mathrm{n}=3$ )

\begin{tabular}{lccccc}
\hline $\begin{array}{l}\text { Sample/ultrasound } \\
\text { power }\end{array}$ & $\begin{array}{c}\text { Storage } \\
(\text { day) }\end{array}$ & $\begin{array}{c}\text { Apparent viscosity } \\
(\mathbf{m P a} \text {, at 100rpm) }\end{array}$ & $\begin{array}{c}\text { Consistency coefficient } \\
\left(\mathbf{K}, \mathbf{m P a} \mathbf{s}^{\mathbf{n}}\right)\end{array}$ & $\begin{array}{c}\text { Flow behavior } \\
\text { index }(\mathbf{n})\end{array}$ & $\begin{array}{c}\text { Coefficient of } \\
\text { determination }\left(\mathbf{R}^{2}\right)\end{array}$ \\
\hline Control & 1 & $174 \pm 39$ & $7.11 \pm 1.98$ & $0.568 \pm 0.025$ & $0.990 \pm 0.004$ \\
& 5 & $145 \pm 29$ & $7.04 \pm 2.34$ & $0.510 \pm 0.055$ & $0.991 \pm 0.001$ \\
$100 \mathrm{~W}$ & 10 & $143 \pm 24$ & $7.41 \pm 1.88$ & $0.480 \pm 0.031$ & $0.988 \pm 0.002$ \\
& 1 & $187 \pm 74$ & $5.85 \pm 2.31$ & $0.672 \pm 0.002$ & $0.985 \pm 0.012$ \\
& 5 & $142 \pm 34$ & $4.58 \pm 1.25$ & $0.659 \pm 0.019$ & $0.977 \pm 0.013$ \\
$125 \mathrm{~W}$ & 10 & $120 \pm 35$ & $3.77 \pm 1.70$ & $0.685 \pm 0.074$ & $0.974 \pm 0.007$ \\
& 1 & $226 \pm 37$ & $5.32 \pm 4.60$ & $0.919 \pm 0.404$ & $0.994 \pm 0.002$ \\
$150 \mathrm{~W}$ & 5 & $208 \pm 9$ & $9.36 \pm 1.58$ & $0.532 \pm 0.046$ & $0.989 \pm 0.001$ \\
& 10 & $169 \pm 0$ & $8.42 \pm 0.93$ & $0.491 \pm 0.040$ & $0.986 \pm 0.005$ \\
& 1 & $244 \pm 84$ & $6.74 \pm 5.40$ & $0.808 \pm 0.253$ & $0.996 \pm 0.002$ \\
& 5 & $234 \pm 11$ & $12.37 \pm 3.27$ & $0.477 \pm 0.077$ & $0.991 \pm 0.000$ \\
& 10 & $202 \pm 8$ & $12.17 \pm 2.90$ & $0.431 \pm 0.065$ & $0.987 \pm 0.002$ \\
\hline
\end{tabular}

drink products, the denaturation of entire whey proteins is critical for a better gel structure formation. Riener et al. (2009) reported that whey protein denaturation ratio in milk samples thermosonicated at 400W for 10 minutes was $50 \%$ less than the ratio in milk samples treated with traditional thermal process at $90^{\circ} \mathrm{C}$ for 10 minutes. The authors stated that the molecular interactions that provide the gel structure formation and stabilization in yoghurts produced with thermosonicated milk samples were different than those in yoghurts produced with traditional thermal processed milk samples. Thermosonication is more likely to promote the disassociation of casein micelles into subunits that can form strong networks by re-aggregating strongly with each other and/or with partially denatured whey proteins during fermentation (Riener et al., 2009). The authors confirmed the hypothesis by comparing scanning electron microscopy (SEM) images of yoghurt samples. The microstructure of yoghurt samples produced with thermosonicated milk was more stringent and complex than the microstructure of control yoghurts, which increased the viscosity obviously.

In this present study, the highest apparent viscosity value (244mPa.s at $100 \mathrm{rpm}$ ) was determined in yoghurt drink produced with milk sonicated at $150 \mathrm{~W}$ ultrasound power for 15 minutes at $70^{\circ} \mathrm{C}$. Apparent viscosity of yoghurt samples increased with the severity of sonication power applied to milk and apparent viscosity values decreased over storage time (Table 4). In yoghurt drink samples, the apparent viscosity decreased with an increase in shear rate (Figs. 2 and 3). Flow behavior indices of yoghurt drink samples ranged from 0.480 to 0.919 , meaning that they all exhibited a non-Newtonian type of flow behavior. Similar results were also reported by Bayraktaroğlu and Obuz (2008) and Ertugay et al. (2012) in yoghurt drinks with different fat contents.

\section{Color}

Color values of yoghurt drink samples determined in CIE (Commission International de L'Eclairage) scale of

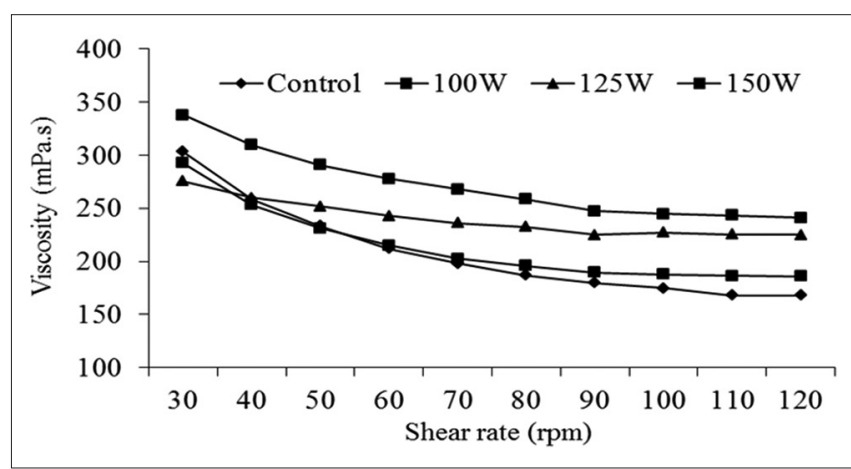

Fig 2. Appearent viscosity values of yoghurt drink samples at different shear rates at the first day of storage

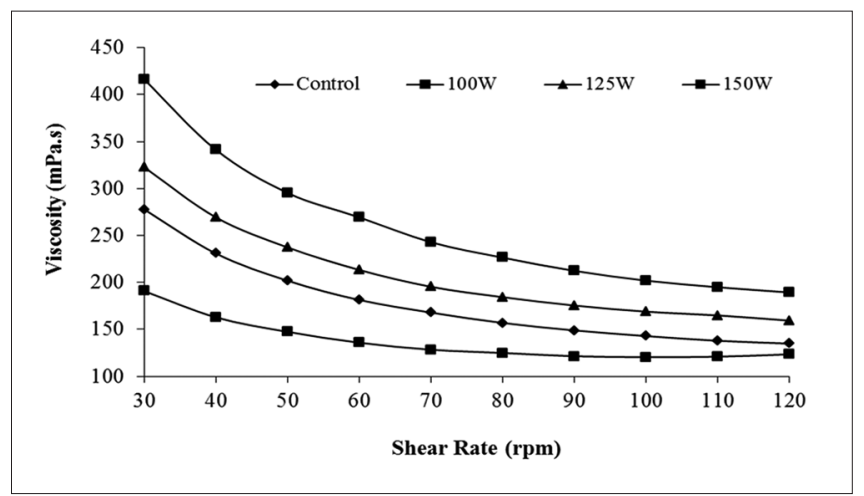

Fig 3. Appearent visscosity values of yoghurt drink samples at different shear rates at the $10^{\text {th }}$ day of storage

$L^{*}, a^{*}$ and $b^{*}$ at the first day of the storage are presented in Table 1 . High $\mathrm{L}^{*}$ value is a significant quality parameter of yoghurt drink. Insignificant differences in L*, a* and b* values were found between yoghurt drinks produced with milk thermosonicated at different ultrasound powers in comparison to control yoghurt drink $(\mathrm{p}>0.05)$. Storage time and its interaction with thermosonication treatment were also insignificant statistically ( $\mathrm{p}>0.05)$. Erkaya et al. (2015) produced yoghurt drinks by diluting yoghurt which had been manufactured with raw milk pasteurized at $90^{\circ} \mathrm{C}$ for $10 \mathrm{~min}$, and the authors found that $\mathrm{L}^{*}$ values of yoghurt 
drinks produced with milk sonicated in an ultrasonic bath at a frequency of $35 \mathrm{kHz}$ for 1,3 and $5 \mathrm{~min}$ followed by heat treatment at 60,70 and $80^{\circ} \mathrm{C}$ changed between $81.22 \pm 0.34$ and $83.62 \pm 0.28$ while $L^{*}$ value of control sample was $83.54 \pm 0.18$. Unlike our results, they reported that $\mathrm{b}^{*}$ values of samples increased with an increase in power and time of ultrasonication. Dissimilarities may arise from the differences in raw materials used and thermosonication conditions. Color values of yoghurt drinks in our study were similar to those reported by Guler and Park (2009) for yoghurt samples.

\section{CONCLUSION}

Overall results indicated that the processing of milk with thermosonication treatment significantly increased viscosity while decreasing serum separation values of yoghurt drinks in comparison to conventional heat treatment $(p<0.01)$. During the storage period, serum separation was not detected in yoghurt drinks produced with milk thermosonicated at $150 \mathrm{~W}$ ultrasound power for $15 \mathrm{~min}$. Under the conditions studied, thermosonication process at different ultrasound powers applied in yoghurt drink production did not alter the proximate composition and color values of final products. Thus, thermosonication can be successfully used as an alternative process to conventional heat treatment with positive effects on serum separation and viscosity properties of yoghurt drinks. Although some evidences concerning to pasteurization effect of ultrasonication have been previously reported for milk (Bermúdez-Aguirre et al. 2009a,b), future studies are needed to determine its pasteurization efficiency under the conditions used and its effect on the sensory properties of final products.

\section{ACKNOWLEDGEMENTS}

This study was financially supported by the Commission of Mehmet Akif Ersoy University Scientific Research Projects (Project No: 0189-NAP-13). The authors are most grateful to Damla Bayana, Aybuke Yazar, Gozde Gul and Gamze Celik Cogal for their technical assistance in laboratory studies.

\section{Authors contributions}

O. Gursoy was the project director and supervised the overall experimental design and wrote the manuscript with co-author Y. Yilmaz. The co-authors (Y. Yilmaz, O. Gokce and K. Ertan) collaborated in the yogurt drinkmaking process, performed compositional (O. Gokce and K. Ertan) and rheological analyses, processed the data and performed statistical analysis (Y. Yilmaz) and revised the manuscript (all authors).

\section{REFERENCES}

Akkaya, L., R. Kara, R. Muduruglu and O. Sagdic. 2015. Survival of Listeria monocytogenes in Ayran, a traditional Turkish fermented milk. Mljekarstvo. 65: 130-137.

Anonymous. 1981. TS 1018 Raw Milk Standard. Turkish Standards Institute, Ankara.

Atamer, M. 1986. Varieties and quality of dairy products, especially cheeses in Turkey. Mljekarstvo, 37: 137-142.

Bayraktaroglu, G. and E. Obuz. 2008. Quality and rheological properties of yoghurt drinks with different fat contents. In: Proceedings of $10^{\text {th }}$ Turkish Food Congress. Publisher Turkish Society of Food Technology, Ankara, p. 825.

Bermúdez-Aguirre, D., M.G. Corradini, R. Mawson and G.V. BarbosaCánovas. 2009. Modeling the inactivation of listeria innocua in raw whole milk treated under thermo-sonication. Innov. Food Sci. Emerg. Technol. 10: 172-178.

Bermúdez-Aguirre, D., R. Mawson, K. Versteeg and G.V. BarbosaCánovas. 2009a. Composition properties, physicochemical characteristics and shelf life of whole milk after thermal and thermo-sonication treatments. J. Food Qual. 32: 183-302.

Bhaskaracharya, R.K., S. Kentish and M. Ashokkumar. 2009. Selected applications of ultrasonics in food processing. Food Eng. Rev. 1: 31-49.

Carcel, J.A., J.V. Garcia-Perez, J. Benedito and A. Mulet. 2012. Food process innovation through new technologies: Use of ultrasound. J. Food Eng. 110: 200-207.

Chandrapala, J., C. Oliver, S. Kentish and M. Ashokkumar. 2012. Ultrasonics in food processing. Ultrason. Sonochem. 19: 975983.

Chemat, F., Z. e-Huma and M.K. Khan. 2011. Applications of ultrasound in food technology: Processing, preservation and extraction. Ultrason. Sonochem. 18: 813-835.

Colakoglu, H. 2010. Effect of Lactic Adjunct Cultures on Conjugated Linoleic Acid Content of Drinking Yoghurt, Ayran. M.Sc. Thesis, Pamukkale University, Denizli, Turkey.

Colakoglu, H. and O. Gursoy. 2011. Effect of lactic adjunct cultures on conjugated linoleic acid (CLA) concentration of yoghurt drink. J. Food Agric. Environ. 9: 60-64.

Demirdoven, A., T. Baysal. 2009. The use of ultrasound and combined technologies in food preservation. Food Rev. Int. 25: 1-11.

Dolatowski, Z.J., J. Stadnik and D. Stasiak. 2007. Applications of ultrasound in food technology. Acta Sci. Pol. Technol. Aliment. 6: 89-99.

Erkaya, T., M. Baslar, M. Sengul and M.F. Ertugay. 2015. Effect of thermo sonication on physicochemical, microbiological and sensorial characteristics of ayran during storage. Ultrason. Sonochem. 13: 406-412.

Ertugay, M.F., M. Baslar, M. Sengul and S. Sallan. 2012. The effect of acoustic energy on viscosity and serum separation of traditional Ayran, a Turkish Yoghurt Drink. Gida. 37: 253-257.

Guler, Z. and Y.W. Park. 2009. Evaluation of chemical and color index characteristics of goat milk, its yoghurt and salted yoghurt. Trop. Subtrop. Agroecosyst. 11: 37-39.

ISO/IDF. 2010. Milk, Cream and Evaporated Milk-Determination of Total Solids Content (ISO6731-IDF21), Brussels, Belgium.

Jambrak, A.R. 2011. Experimental design and optimization of ultrasound treatment of food products. J. Food Process. Technol. 2: 102e.

Jambrak, A.R., D. Lerda, R. Mirčeta, M. Šimunek, V. Lelas, F. Chemat, Z. Herceg and V. Batur. 2012. Experimental design and optimization of ultrasound treatment: Functional and physical 
properties of sonicated ice cream model mixtures. J. Food Process. Technol. 3: 145.

Knorr, D., M. Zenker, V. Heinz and D.U. Lee. 2004. Applications and potential of ultrasonics in food processing. Trends Food Sci. Technol. 15: 261-266.

Kocak, C. and Y.K. Avsar. 2010. Ayran: Microbiology and technology. In: Yildiz, F (Ed.), Development and Manufacture of Yoghurt and Other Functional Dairy Products, CRC Press, New York, p. 123-141.

Koksoy, A. and M. Kilic. 2003. Effects of water and salt level on rheological properties of ayran, a Turkish yoghurt drink. Int. Dairy J. 13: 835839.

Lucey, J.A. 2004. Cultured dairy products: An overview of their gelation and texture properties. Int. J. Dairy Technol. 57: 77-84.

Mason, T.J., L. Paniwnyk and J.P. Lorimer. 1996. The uses of ultrasound in food technology. Ultrason. Sonochem. 3: S253-S260.

Nguyen, N.H.A., S.G. Anema. 2010. Effect of ultrasonication on the properties of skim milk used in the formation of acid gels. Innov. Food Sci. Emerg. Technol. 11: 616-622.

Oysun, G. 2001. Analyses Methods in Milk and Dairy Products, Ege University Agricultural Faculty Press, Izmir.

Ozdemir, U. and M. Kilic. 2004. Influence of fermentation conditions on rheological properties and serum separation of ayran. J.
Texture Stud. 35: 415-428.

Pingret, D., A.S. Fabiano-Tixier and F. Chemat. 2013. Degradation during application of ultrasound in food processing: A review. Food Control. 31: 593-606.

Riener, J., F. Noci, D.A. Cronin, D.J. Morgan and J.G. Lyng. 2009. The effect of thermosonication of milk on selected physicochemical and microstructural properties of yoghurt gels during fermentation. Food Chem. 114: 905-911.

Soria, A.C. and M. Villamiel. 2010. Effect of ultrasound on the technological properties and bioactivity of food: A review. Trends Food Sci. Technol. 21: 323-331.

Steffe, J.F. 1996. Rheological Methods in Food Process Engineering, $2^{\text {nd }}$ ed. Freeman Press, East Lansing, MI, USA.

Tamucay-Ozunlu, B. and C. Kocak. 2010a. Effect of homogenization treatments of milk under different pressures on quality of ayran. Gida. 35: 189-195.

Tamucay-Ozunlu, B. and C. Kocak. 2010b. Effect of ending the incubation at different pHs on quality of Ayran. Gida. 35: 113-119.

Tonguc, I.E. 2006. A Research on Probiotic Yoghurt Drink Production, M.Sc. Thesis, Ege University, Izmir, Turkey.

Uzunoglu, T.P. 2012. The Effect of High Power Ultrasound Treatment on Microbiological and Sensory Properties of Ayran with Short and Long Shelf Life, M.Sc. Thesis, Istanbul Technical University, Istanbul, Turkey. 